\title{
A Solar Regenerative Thermoelectrochemical Converter (RTEC)
}

\section{Executive Summary of Final Subcontract Report}

C. W. Townsend

J. McHardy

Hughes Aircraft Company

El Segundo, California

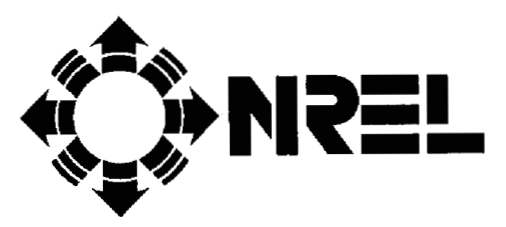

National Renewable Energy Laboratory A Division of Midwest Research Institute Operated for the U.S. Department of Energy Under Contract No. DE-AC02-83CH10093 


\section{A Solar Regenerative Thermoelectrochemical Converter (RTEC) \\ Executive Summary of Final Subcontract Report}

C. W. Townsend

J. McHardy

Hughes Aircraft Company

El Segundo, California

NREL Technical Monitor:

Meir Carasso

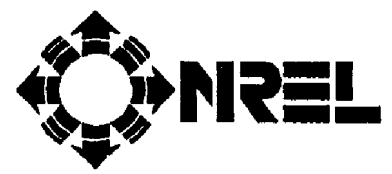

National Renewable Energy Laboratory

(formerly the Solar Energy Research Institute) 1617 Cole Boulevard

Golden, Colorado 80401-3393

A Division of Midwest Research Institute Operated for the U.S. Department of Energy under Contract No. DE-AC02-83CH10093

Prepared under Subcontract No. ZX-8-07057-1

February 1992 
On September 16, 1991 the Solar Energy Institute was designated a national laboratory, and its name was changed to the National Renewable Energy Laboratory.

\section{NOTICE}

This report was prepared as an account of work sponsored by an agency of the United States government. Neither the United States government nor any agency thereof, nor any of their employees, makes any warranty, express or implied, or assumes any legal liability or responsibility for the accuracy, completeness, or usefulness of any information, apparatus, product, or process disclosed, or represents that its use would not infringe privately owned rights. Reference herein to any specific commercial product, process, or service by trade name, trademark, manufacturer, or otherwise does not necessarily constitute or imply its endorsement, recommendation, or favoring by the United States government or any agency thereof. The views and opinions of authors expressed herein do not necessarily state or reflect those of the United States government or any agency thereof.

\section{Printed in the United States of America Available from: \\ National Technical Information Service \\ U.S. Department of Commerce \\ 5285 Port Royal Road \\ Springfield, VA 22161}

Price: Microfiche A01

Printed COpy AO3

Codes are used for pricing all publications. The code is determined by the number of pages in the publication. Information pertaining to the pricing codes can be found in the current issue of the following publications which are generally available in most libraries: Energy Research Abstracts (ERA); Government Reports Announcements and Index (GRA and I); Scientific and Technical Abstract Reports (STAR); and publication NTIS-PR-360 available from NTIS at the above address. 


\title{
Table of Contents
}

\begin{abstract}
Page
List of Figures $\ldots \ldots \ldots \ldots \ldots \ldots \ldots \ldots \ldots \ldots \ldots \ldots \ldots$ iv

Acknowledgment $\ldots \ldots \ldots \ldots \ldots \ldots \ldots \ldots \ldots \ldots \ldots \ldots \ldots$

Exeuctive Summary . . . . . . . . . . . . . . . . . . . . . 1

Selected Distribution List $\ldots \ldots \ldots \ldots \ldots \ldots \ldots \ldots \ldots \ldots \ldots \ldots \ldots \ldots \ldots$
\end{abstract}




\section{List of Figures}

Page

Figure 1. Closed-loop RTEC system uses heat to separate acid and base chemicals, which then recombine to produce electric

power ......................... 2 


\section{Acknowledgment}

Funding for this project was provided by a cost-sharing arrangement between the United States Department of Energy, Solar Thermal Program, and Hughes Aircraft Company. The authors wish to express their thanks for this support. Next, we gratefully acknowledge the help we received from the following people at the Solar Energy Research Institute (SERI):

Dr. Gerry Nix for providing initial focus and getting the project off to a good start, Dr. Meir Carasso for his tact and leadership in keeping the project on track and for directing the parallel effort at SERI, and Mr. George Yeagle for installing the SERI-built regenerative stripper in our laboratory and teaching us how to run it.

Finally, we wish to thank all our colleagues at Hughes for their help and guidance, in particular Dr. Frank Ludwig for his insights and valuable suggestions at critical points during the work; and Lin Higley, Andy Kindler, Bruce Eliash, Don Helber, Bruce Buller, and Dhirin Mehta for their skillful and diligent work in the laboratory. 


\section{Executive Summary}

This is the executive summary of Hughes Aircraft Company's final report on research contract ZX-8-07057-1 from the Solar Energy Research Institute (SERI), Golden, Colorado. The full report, which contains a detailed description of the two-year effort by both SERI and Hughes, is currently subject to a government secrecy order which precludes public release of the information. Copies of the full report will be made available for general release whenever that order is lifted.

The contract covered Phase III of a program to investigate a regenerative thermoelectrochemical converter (RTEC) for converting solar thermal energy into electricity. The work at Hughes was performed in conjunction with a complementary effort at SERI.

Several methods have been proposed for the collection of solar thermal energy, but few viable options exist for the conversion and storage of that energy. The choice is particularly limited for small, dispersed systems such as those using parabolic dish collectors. The more established energy conversion methods tend to be inefficient or unreliable on the small scale, while newer methods require a bottoming cycle to achieve adequate efficiencies.

The RTEC operates with high, scale-independent efficiencies and has a built-in capacity for energy storage. For the first time, therefore, efficient, cost-effective conversion and storage of energy are within reach for the whole range of solar thermal energy systems, regardless of scale.

The RTEC converts heat to electricity in a two-stage cycle that couples a hightemperature chemical process with a low-temperature electrochemical process. It comprises two major subsystems: an electrochemical converter and a thermal regenerator. The regenerator is further divided into a stripper and a condenser. The converter and the condenser subsystems were developed at Hughes. SERI took primary responsibility for the high-temperature stripper unit, in which solar heat input is converted to chemical energy. 


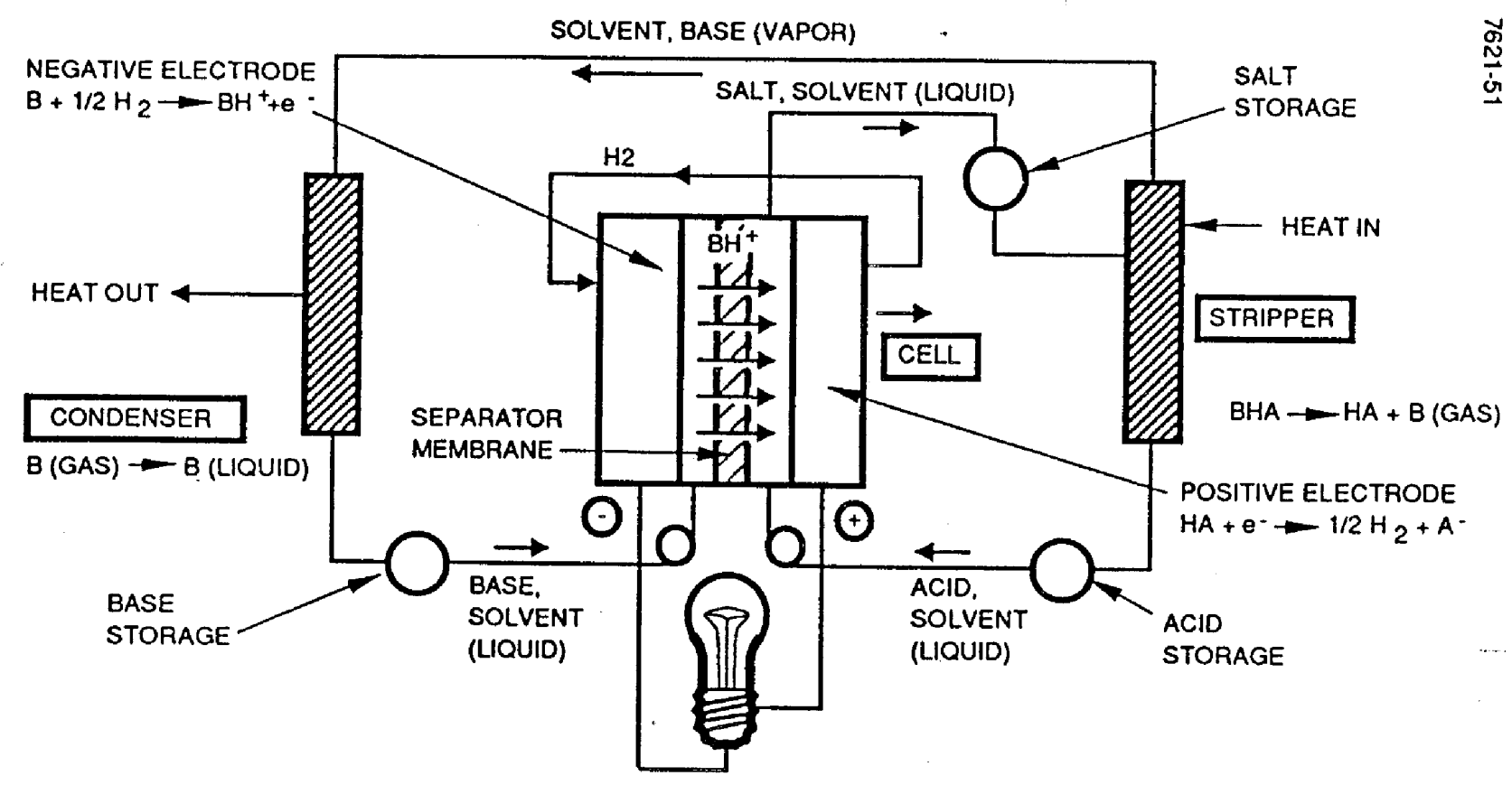

Figure 1. Closed-loop RTEC system uses heat to separate acid and base chemicals, which then recombine to produce electric power.

In the RTEC system (Figure 1), a salt is chemically converted at high temperature to an acid and a base. These chemicals are cooled and fed into an electrochemical cell consisting of two hydrogen electrodes separated by an ion-selective membrane. Hydrogen is evolved at the acid electrode and consumed at the base electrode, yielding electric power and a salt. The salt is returned to the regenerator, completing the cycle. When required, the two halves of the system can be uncoupled and the chemicals held in storage.

The program was divided into several tasks in which electrochemical and thermal subsystems were first developed separately and then integrated into a closed loop. Electrochemical cell research focused on several different types of membranes and electrodes and on their interaction with the working fluids. Open-circuit voltages of 500 to $600 \mathrm{mV}$ were found with typical working fluid compositions. At peak power, current densities of $>200 \mathrm{~mA} / \mathrm{cm}^{2}$ were attained, far exceeding the program goal of $50 \mathrm{~mA} / \mathrm{cm}^{2}$. A corresponding power density of $50 \mathrm{~mW} / \mathrm{cm}^{2}$ was measured. The electrodes were found to be free of activation polarization, indicating that catalysis of the electrochemical reactions is relatively simple. 
Scaled-up studies of the electrochemical cell showed that the electrode area and number of cells can be increased without loss of performance. A two-cell bipolar stack with 6-by-6-in. electrodes was constructed. This stack produced 16 watts, exceeding the program goal of 10 watts.

Condenser research showed that the chemistry of the alkaline part of the system is ideal for the RTEC. The kinetics of the condensation/absorption process were found to be rapid, and a scaled-up condenser was constructed.

Regeneration studies established that thermal dissociation of the salt (produced in the electrochemical cell) in the stripper occurs rapidly and with yields of up to $41 \%$. The acid products of the regenerator can be adjusted in composition to match the requirements of the cell. Suitable corrosion-resistant construction materials were identified. However, maintaining high-temperature seals proved to be difficult.

Closed-loop testing proved that the products of the cell match the products of the regeneration process, demonstrating that long-term closed-loop operation is possible. A net conversion efficiency of heat to electricity of $11.76 \%$ was measured for the closed-loop system.

An analysis of engineering and cost factors showed that the system is competitive with alternative technologies. Key to improving system efficiency beyond the existing levels is the development of a cell membrane with reduced solvent transport rates. This change will allow efficiencies of 30\%-40\%. Limited tests indicate that reduced solvent transport can be accomplished, but with the added benefit of using low-cost materials. Furthermore, the relatively simple catalysis of the hydrogen electrode reaction suggests that low-cost catalysts can be used. Based on these projected improvements, costs for the RTEC system (exclusive of the solar concentrator) can be as low as $\$ 43$ per kilowatt, with a power density of 309 watts per pound. 


\section{Selected Distribution List}

U.S. Department of Energy

Deputy Assistant Secretary for Utility Technologies

CE-30, Forrestal Building

Room 6E-036

1000 Independence Avenue, SW

Washington, DC 20585

Attn: R. L. San Martin

U.S. Department of Energy

Forrestal Building

Code CE-331

1000 Independence Avenue, SW

Washington, DC 20585

Attn: Alan Streb

U.S. Department of Energy

Forrestal Building

Code CE-331, 5H-047, FORS

1000 Independence Avenue, SW

Washington, DC 20585

Attn: G. Burch

U.S. Department of Energy

Forrestal Building

Code CE-222

1000 Independence Avenue, SW

Washington, DC 20585

Attn: F. Wilkins

U.S. Department of Energy (2)

Albuquerque Operations Office

P.O. Box 5400

Albuquerque, NM 87115

Attn: D. Graves, G. Tennyson

U.S. Department of Energy

San Francisco Operations Office

1333 Broadway

Oakland, CA 94612

Attn: R. Hughey
U.S. Department of Energy

SERI Area Site Office

1617 Cole Boulevard

Golden, CO 80401

Attn: P. Kearns

Arizona Solar Energy Office

Department of Commerce

$1700 \mathrm{~W}$. Washington, 5th floor

Phoenix, AZ 85007

Attn: Dr. Frank Mancini

Asinel

Ctra. Villaviciosa de Odon

a Mostoles

$\mathrm{Km} \mathrm{1,700}$

28935 Mostoles

Madrid, Spain

Attn: Jesus M. Mateos

Babcock and Wilcox

91 Stirling Avenue

Barberton, OH 44203

Attn: D. Young

Battelle Pacific Northwest

Laboratory

P.O. Box 999

Richland, WA 99352

Attn: J. A. Dirks

Bechtel National, Inc.

50 Beale Street

50/15 D8

P.O. Box 3965

San Francisco, CA 94106

Attn: P. DeLaquil 
Black \& Veatch Consulting Engineers

P.O. Box 8405

Kansas City, MO 64114

Attn: J. E. Harder

Tom Brumleve

1512 Northgate Road

Walnut Creek, CA 94598

California Energy Commission

1516 Ninth Street, M-S 43

Sacramento, CA 95814

Attn: A. Jenkins

California Polytechnic University

Dept. of Mechanical Engineering

3801 West Temple Avenue

Pomona, CA 91768-4062

Attn: W. Stine

California Public Utilities

Commission

Resource Branch, Room 5198

455 Golden Gate Avenue

San Francisco, CA 94102

Attn: T. Thompson

Centro Investigaciones Energetica

(1)

Medroansental Technologie

(CIEMAT)

Avda. Complutense, 22

28040 Madrid, Spain

Attn: M. Macias, M. Romero,

E. Conejero, J. M. Figarola

DLR (2)

Linder Hohe

5000 Koln 90

Germany

Attn: Dr. Manfred Becker

Dr.-Ing. Manfred Bohmer
Electric Power Research Institute (2)

P.O. Box 10412

Palo Alto, CA 94303

Attn: J. Bigger, E. DeMeo

Engineering Perspectives

20 19th Avenue

San Francisco, CA 94121

Attn: John Doyle

Flachglas Solartechnik GmbH

Sonnesstr. 25

D-8000 Munchen 1

Germany

Attn: Dr. Michael Geyer

Foster Wheeler Solar Development Corporation (2)

12 Peach Tree Hill Road

Livingston, NJ 07039

Attn: S. F. Wu, R. Zoschak

Georgia Power

7 Solar Circle

Shenandoah, GA 30265

Attn: Ed. Ney

Hughes Aircraft Company (2)

Electro-Optical and Data Systems

Group

2000 East El Segundo Boulevard

P.O. Box 902

El Segundo, CA 90245

Attn: C. W. Townsend, J. McHardy

Interatom $\mathrm{GmbH}$ (2)

D-5060 Bergisch-Gladbach

Germany

Attn: M. Kiera, W. Meinecke

Los Angeles Department of Water and Power

Alternate Energy Systems, \# 661A

111 North Hope Street

Los Angeles, CA 90012

Attn: Bill Engels 
Luz International (2)

924 Westwood Blvd.

Los Angeles, CA 90024

Attn: D. Kearney, M. Lotker

Meridian Corporation

4300 King Street

Suite 400

Alexandria, VA 22302-1508

Attn: D. Kumar

MITI

Electrotechnical Laboratory

Solar Energy Applications Section

1-1-4 Umezono, Tsukuba

Ibaraki 305, Japan

Attn: Koichi Sakuta

ORMAT Energy Systems, Inc.

610 East Glendale Avenue

Sparks, NV 89431-5811

Attn: Dr. Lucien Bronicki

Pacific Gas and Electric Company

3400 Crow Canyon Road

San Ramon, CA 94526

Attn: G. Braun

Platforma Solar de Almeria

Aptdo. 7

Tabernas (Almeria)

E-04200, Spain

Attn: A. Sevilla

Polydyne, Inc.

1900 S. Norfolk Street, Suite 209

San Mateo, CA 94403

Attn: P. Bos

PSI (2)

$\mathrm{CH}-5303$ Wurenlingen

Switzerland

Attn: W. Durish, P. Kesselring
Public Service Co. of Colorado

System Planning

5909 East 38th Avenue

Denver, CO 80207

Attn: D. Smith

Public Service Co. of New Mexico

(2)

M/S 0160

Alvarado Square

Albuquerque, NM 87158

Attn: T. Ussery, A. Martinez

San Diego Gas and Electric

Company

P.O. Box 1831

San Diego, CA 92112

Attn: R. Figueroa

SCE

P.O. Box 800

Rosemead, CA 91770

Attn: W. vonKleinSmid

Science Applications

International Corp.

10343 Roselle Street

San Diego, CA 92121

Attn: K. Beninga

Solar Kinetics, Inc. (1)

P.O. Box 540636

Dallas, TX 75354-0636

Attn: J. A. Hutchison,

A. Konnerth, P. Schertz

Solar Power Engineering Company

P.O. Box 91

Morrison, CO 80465

Attn: H. C. Wroton

Solar Steam

P.O. Box 32

Fox Island, WA 98333

Attn: D. Wood 
Stearns Catalytic Corporation

P.O. Box 5888

Denver, CO 80217

Attn: T. E. Olson

Stone and Webster

Engineering Corp.

P.O. Box 1214

Boston, MA 02107

Attn: R. W. Kuhr

Sulzer Bros, Ltd.

New Technologies

$\mathrm{CH}-8401$ Winterthur

Switzerland

Attn: Hans Fricker, Manager

Tom Tracey

6922 South Adams Way

Littleton, CO 80122

United Solar Tech, Inc.

3434 Martin Way

Olympia, WA 98506

Attn: R. J. Kelley
University of Arizona

Engineering Experimental Station

Harvil Bldg., Room 151-D

Tucson, AZ 85721

Attn: Don Osborne

University of Utah

Mechanical and Industrial

Engineering

Salt Lake City, UT 84112

Attn: B. Boehm

Eric Weber

302 Caribbean Lane

Phoenix, AZ 85022

National Renewable Energy Laboratory (5) 1617 Cole Blvd.

Golden, CO 80401

Attn: B. Gupta, L. M. Murphy,

J. Anderson, G. Nix,

M. Carasso

Sandia National Laboratories,

Albuquerque

6216 B. W. Marshal

6217 B. C. Klimas

6215 J. T. Holmes

6216 C. E. Tyner 


\begin{tabular}{|c|c|c|c|}
\hline $\begin{array}{l}\text { DOCUMENT } \\
\text { CONTROL PAGE }\end{array}$ & $\begin{array}{l}\text { 1. SERI Report No. } \\
\qquad \text { TP-253-4020 }\end{array}$ & $\begin{array}{l}\text { 2. NTIS Accession No. } \\
\text { DE91002126 }\end{array}$ & 3. Recipient's Accession No. \\
\hline \multirow{2}{*}{\multicolumn{3}{|c|}{$\begin{array}{l}\text { 4. Title and Subtitle } \\
\text { A Solar Regenerative Thermoelectrochemical Converter (RTEC): } \\
\text { Executive Summary of Final Subcontract Report }\end{array}$}} & $\begin{array}{l}\text { 5. Publication Date } \\
\text { February } 1992\end{array}$ \\
\hline & & & 6. \\
\hline \multicolumn{3}{|c|}{$\begin{array}{l}\text { 7. Author(s) } \\
\text { C. W. Townsend, J. McHardy }\end{array}$} & 8. Performing Organization Rept. No. \\
\hline \multirow{2}{*}{\multicolumn{3}{|c|}{$\begin{array}{l}\text { 9. Performing Organization Name and Address } \\
\text { Hughes Aircraft Company } \\
\text { Electro-Optical and Data Systems Group } \\
\text { 2000 East El Segundo Boulevard/P.O. Box } 902 \\
\text { El Segundo, California } 90245\end{array}$}} & $\begin{array}{l}\text { 10. Project/Task/Work Unit No. } \\
\text { SI111010 }\end{array}$ \\
\hline & & & $\begin{array}{l}\text { 11. Contract (C) or Grant (G) No. } \\
\text { (C) DE-AC02-83CH10093 } \\
\text { (G) }\end{array}$ \\
\hline \multirow{2}{*}{\multicolumn{3}{|c|}{$\begin{array}{l}\text { 12. Sponsoring Organization Name and Address } \\
\text { Solar Energy Research Institute } \\
\text { 1617 Cole Boulevard } \\
\text { Golden, Colorado } 80401\end{array}$}} & $\begin{array}{l}\text { 13. Type of Report \& Period Covered } \\
\text { Subcontract report summary }\end{array}$ \\
\hline & & & 14. \\
\hline \multicolumn{4}{|c|}{$\begin{array}{l}\text { 15. Supplementary Notes } \\
\text { SERI Technical Monitor: Meir Carasso }\end{array}$} \\
\hline \multicolumn{4}{|c|}{$\begin{array}{l}\text { 16. Abstract (Limit: } 200 \text { words) } \\
\text { This is an executive summary of a final subcontract report that describes the successful completion of a closed- } \\
\text { loop demonstration of a regenerative thermoelectrochemical device using solar heat input for the production of } \\
\text { electricity. The full report, which contains a detailed description of the two-year effort, is currently subject to a } \\
\text { government secrecy order which precludes public release of the information. Copies of the full report will be } \\
\text { made available for general release whenever the secrecy order is lifted. }\end{array}$} \\
\hline \multicolumn{4}{|c|}{$\begin{array}{l}\text { 17. Document Analysis } \\
\text { a. Descriptors } \\
\text { Energy Storage; Electrochemical Energ } \\
\text { b. Identifiers/Open-Ended Terms }\end{array}$} \\
\hline \multirow{2}{*}{\multicolumn{3}{|c|}{$\begin{array}{l}\text { 18. Availability Statement } \\
\text { National Technical Information Service } \\
\text { U.S. Department of Commerce } \\
5285 \text { Port Royal Road } \\
\text { Springfield, VA } 22161\end{array}$}} & $\begin{array}{l}\text { 19. No. of Pages } \\
13\end{array}$ \\
\hline & & & $\begin{array}{l}\text { 20. Price } \\
\text { A03 }\end{array}$ \\
\hline
\end{tabular}

Form No. 0069E (6-30-87) 